\title{
DANIEL MUNDURUKU E KAKA WERÁ JECUPÉ: UMA EXPERIÊNCIA DE LEITURA DO MUNDO DO OUTRO
}

ALANA FRIES ${ }^{1}$

UFRGS

\begin{abstract}
RESUMO: Este artigo propõe que a experiência de leitura de textos de autoria indígena se mostra repleta de elementos que ultrapassam o âmbito literário, assim como os processos vivenciados por esses autores. Para alcançar o relato analítico das leituras de "Karaíba: uma história do pré-Brasil", de Daniel Munduruku, e "Todas as vezes que dissemos adeus", de Kaka Werá Jecupé, percorre-se uma reflexão que abrange elementos históricos e sociológicos que compõem a relação da sociedade não indígena com "o outro" indígena, e as noções de escrita e oralidade, de modo a identificar o que pode existir virtualmente entre autor, leitor e obra, interagindo com as possíveis leituras que os textos podem proporcionar.
\end{abstract}

PALAVRAS-CHAVE: Literatura indígena; Daniel Munduruku; Kaka Werá Jecupé; leitura; escrita.

ABSTRACT: This paper proposes that the reading of indigenous authors' works is filled with elements that surpass the literary field, as much as the processes experienced by these authors. Before reaching the analysis of Karaíba: uma história do pré-Brasil, by Daniel Munduruku, and Todas as vezes que dissemos adeus, by Kaka Werá Jecupé, the relationship between the indigenous and non-indigenous society and the notions of writing and orality shall be brought to discussion under historical and sociological terms, in order to identify what may virtually exist amongst the writer, the reader and the literary piece, interacting with possible readings the pieces may offer.

KEYWORDS: Indigenous Literature; Daniel Munduruku; Kaka Werá Jecupé; reading; writing.

Com a tarefa de pensar a voz e a escrita "do outro" através das obras Karaíba: uma história do pré-Brasil, de Daniel Munduruku, e Todas as vezes que dissemos adeus, de Kaka Werá Jecupé, para um seminário acadêmico, a experiência de leitura se mostrou impregnada de elementos que extrapolavam âmbitos estritamente literários. Este

\footnotetext{
${ }^{1}$ Graduanda do curso de Bacharelado em Letras da Universidade Federal do Rio Grande do Sul, pesquisadora vinculada ao Núcleo de Antropologia das Sociedades Indígenas e Tradicionais. E-mail: friesalana@gmail.com.
}

Espaço Ameríndio, Porto Alegre, v. 7, n. 1, p. 287-308, jan./jun. 2013. 
ALANA FRIES - Daniel Munduruku e Kaka Werá Jecupé...

artigo propõe que a relação do leitor com as literaturas de autoria indígena, assim como os processos pelos quais passam os autores, é complexificada por motivos históricos, sociológicos e culturais; e busca identificar o que existe virtualmente entre o autor, o leitor e essas obras. Para alcançar o relato analítico da experiência de escrita e de leitura dos dois títulos supracitados, parte-se da reflexão sobre a relação entre a sociedade não indígena com o indígena (ou a imagem historicamente estabelecida que se tem dele), relações de poder que permeiam as noções de tradição escrita e tradição oral, e o desenvolvimento das literaturas (no sentido canônico do termo) de autoria indígena.

\section{Que outro?}

Pensar a voz e a escrita "do outro" parece insuficiente se antes não buscarmos entender o que é que chamamos de outro e que representações e significações fazemos dele. Quando nos dedicamos ao texto de um autor indígena, não somos sujeitos livres de concepções ainda que mínimas - acerca da identidade, cultura e história indígenas. Até que ponto esses pré-conceitos influenciam a experiência de leitura e de que maneira essa recente literatura indígena contribui com a formação e reformulação do nosso entendimento sobre esses seres que chamamos de índios? Mais: dentro de um contexto histórico de dominação e negligência, o que significa para essas aproximadamente 250 etnias que existem e resistem hoje no país tomar parte em um veículo de comunicação e expressão tradicionalmente tão exclusivo e classista?

Colombo um dia chamou os povos da América de índios, os habitantes das Índias (lugar onde acreditava estar), instaurando um termo que reduziria diversos grupos étnicos a uma só nomenclatura que conota até hoje uma relação de poder entre colonizador e colonizado. Com a chegada do colonizador às terras que hoje chamamos Brasil, no século XVI, passou-se a registrar o que existia neste lado do Atlântico, tanto com o objetivo de informar a Coroa sobre o desenvolvimento de seu empreendimento colonial quanto para alimentar o fetiche da população europeia pelo novo e pelo exótico. Chamou-se essa literatura 
ALANA FRIES - Daniel Munduruku e Kaka Werá Jecupé...

de informativa ou de viagem, tendo como alguns se seus expoentes Pero de Magalhães Gândavo, Hans Staden, Jean de Léry e até mesmo o jesuíta Manuel da Nóbrega. Ainda que não dispensassem uma visão eurocentrada das sociedades nativas, esses textos já atestavam a existência povos distintos em costumes, língua etc. Hoje, apesar de informações detalhadas sobre as diversas etnias, sua história, costumes, organização social, língua e situação atual poderem ser facilmente acessadas - além da vasta produção literária e acadêmica, existem domínios especializados na internet, como o Povos Indígenas no BrasiR -, é comum utilizarmos apenas a denominação índio.

As línguas indígenas trataram de revidar: se seus etnônimos muitas vezes significam simplesmente gente - como, por exemplo, a'uwe uptabi, que é como os Xavante chamam a si mesmos, significa gente de verdade -, os termos existentes nessas linguagens para se referir aos brancos costumam significar aqueles que não são [etnônimo], aqueles que não são gente de acordo com aquilo que entendemos por gente - o outro. Os Guarani, por exemplo (não são os únicos), são mais específicos: os juruá são "os homens de palavras vazias".

Durante sua fala em uma conferência facilitada pelo Núcleo de Antropologia das Sociedades Indígenas e Tradicionais (NIT) da Universidade Federal do Rio Grande do Sul (UFRGS), realizada nessa universidade em maio de 2012, Davi Kopenawa, reconhecida liderança yanomami, usou várias vezes a palavra napë. Na sua língua, ela designa o estrangeiro - em princípio, não só o branco, mas também índios de outras etnias. Entretanto, o xabori citava constantemente os "parentes" Guarani, Charrua, Kaingang, Xokleng etc., reservando napë para se referir ao não índio.

Para além dos termos referenciais, passemos a pensar numa visão mais complexa (e idealmente completa) que cultivamos desses outros; uma visão que já abarca outras significações e representações que foram sendo acumuladas ao longo da história, enquanto desenvolvíamo-nos política e socialmente e procurávamos estabelecer uma identidade nacional.

A professora e pedagoga Ludmila Ligório, ao perceber os equívocos do material didático fornecido pelo governo ao tratar de

\footnotetext{
${ }^{2}$ http://pib.socioambiental.org/pt .
}

Espaço Ameríndio, Porto Alegre, v. 7, n. 1, p. 287-308, jan./jun. 2013. 
ALANA FRIES - Daniel Munduruku e Kaka Werá Jecupé...

história e cultura indígenas, realizou uma atividade de pesquisa com alunos da quarta série do ensino fundamental de uma escola pública de Porto Alegre/RS. Quando questionados sobre o que sabiam dos povos indígenas, surgiram, entre outras, as seguintes respostas: "usam tinta para se pintar" e "não têm roupa" (LIGÓRIO, 2008, p. 113). Se examinarmos a Carta de Pero Vaz de Caminha ao rei D. Manuel de Portugal, datada de maio de 1500, alguns aspectos são recorrentes durante a descrição dos nativos: "Trazem todos as testas, de fonte a fonte, tintas de tintura preta, que parece uma fita preta da largura de dois dedos" (CAMINHA, 2012, p. 9), "(...) e suas vergonhas tão nuas, e com tanta inocência assim descobertas, que não havia nisso desvergonha nenhuma"(CAMINHA, 2012, p. 8). É impressionante constatar que esse tipo de característica ainda se destaca na construção de representações que fazemos dos povos indígenas, cinco séculos depois.

Àquelas respostas dadas pelos alunos primários durante a pesquisa da professora Ludmila somam-se outras, igualmente superficiais e homogeneizantes, demonstrando como ainda ignoramos a diversidade cultural dos povos indígenas, assim como permanecemos indiferentes às questões geradas pelos novos paradigmas que compõem a atual relação do indígena englobado na nossa sociedade não indígena: "moram na oca", "usam tanga" (LIGÓRIO, 2008, p. 113); "a principal forma de trabalho do índio é pedindo esmola", "eles têm tribos porque não têm tijolo e cimento para fazer casas", "alguns são canibais porque não têm o que comer" (LIGÓRIO, 2008, p. 117); "agora eles têm roupas, mas agora um pouco rasgadas e de pé descalço" (LIGÓRIO, 2008, p. 120).

Parece que esse imaginário constituído de estereótipos (é notável a associação do índio à pobreza material, o que reflete a nossa concepção de relacionar o ser ao ter), essas opiniões estanques acerca da entidade índio no Brasil sejam comumente absorvidas pelas crianças na falta de algo mais concreto e sigam praticamente as mesmas ao longo da formação escolar e social do brasileiro. De gente de tal inocência que a esquadra de Cabral declarou encontrar, passaram, durante o período colonial, a preguiçosos e arredios que não gostavam de trabalhar. Do selvagem do século XIX que precisava ser exterminado 
ALANA FRIES - Daniel Munduruku e Kaka Werá Jecupé...

em prol do projeto modernizante do príncipe regente, resistiram ao século XX, quando, segundo a proposição de Viveiros de Castro (2006), não se falava em índios, sim em índios ainda, aqueles condenados (pelo Estado e pelo estado das coisas) ao estágio transitório entre o ser selvagem e o ser civilizado. Alcançaram o século XXI para não raro figurarem na grande mídia reduzidos a baderneiros e ladrões: na televisão, índios aparecem interrompendo estradas, organizando violentos protestos em sedes de órgãos públicos; para o Poder Legislativo, índios atrapalham o desenvolvimento econômico da pátria ao serem titulares de terras perfeitamente produtivas 3 ; nas universidades públicas, índios usurpam vagas dos estudantes legítimos.

O tempo passou, mas os equívocos parecem ser ainda os mesmos, guardadas as devidas proporções, uma vez que muita coisa também aconteceu para melhor. $O$ índio se tornou sujeito de direito, as políticas indigenistas têm aumentado, o número de lideranças indígenas de expressão nacional e internacional é crescente, as novas mídias digitais têm tido papel significativo na circulação de informação e mobilização social e, mais, os povos indígenas estão atualizando os rituais antropofágicos de seus antepassados: buscando aprender como a sociedade não indígena funciona, indo à cidade estudar e representarse politicamente - devorando o inimigo para obter dele sua força, se preparando para os próximos combates, usando os próprios meios políticos e burocráticos do homem branco para garantir o poder sobre si mesmo.

O objetivo deste trabalho é alcançar algum tipo de entendimento a partir das recentes literaturas e escritores indígenas que têm se destacado no cenário literário nacional - em especial, Daniel Munduruku e Kaka Werá Jecupé, através de suas obras Karaíba: uma história do préBrasil e Todas as vezes que dissemos adeus, respectivamente. Para tanto, antes buscaremos entender o que é escrita e o que é oralidade; o que é tradição e literatura oral; qual foi o trajeto percorrido pelo indígena até alcançar o status de escritor; e, principalmente, por que pensar isso tudo é da nossa conta. Uma reflexão puramente teórica e

\footnotetext{
${ }^{3}$ A Proposta de Emenda à Constituição no 215/2000 prevê a transferência de competência do Executivo para o Legislativo no que diz respeito à demarcação de terras, e a revisão das demarcações já homologadas. Em tramitação no momento (junho de 2013). Fonte: http://www.camara.gov.br/proposicoesWeb/fichadetramitacao?idProposicao =14562.
}

Espaço Ameríndio, Porto Alegre, v. 7, n. 1, p. 287-308, jan./jun. 2013. 
ALANA FRIES - Daniel Munduruku e Kaka Werá Jecupé...

objetiva se torna quase impossível de ser realizada. Viveiros de Castro (2006) avisou: no Brasil, todo mundo é índio, exceto quem não é.

\section{Voz e escuta : escrita e leitura}

Antes de passar à análise das literaturas escritas indígenas, partindo do princípio de que elas provêm de membros de sociedades de tradição oral, vamos discutir alguns pontos históricos e conceituais, utilizando alguns exemplos práticos para responder brevemente as seguintes questões: São oralidade e escrita práticas primitiva e civilizada, respectivamente? A legitimidade da construção e manutenção de saberes reside exclusivamente na escrita? O que é uma sociedade de tradição oral e como ela produz literatura? A tradição oral exclui a possibilidade de tradição escrita e vice-versa?

Eric Havelock (1995) questiona o processo histórico através do qual a escrita acabou tornando-se o meio de expressão legítimo, em detrimento da oralidade, que é condição biológica inerente ao ser humano:

A cultura escrita, em qualquer estágio de seu desenvolvimento e em termos de tempo evolutivo, é mera 'presunção', um exercício artificial, um produto da cultura, não da natureza, imposto ao homem natural (HAVELOCK, 1995, p. 27).

Além do mais, a escrita é uma ferramenta que historicamente pertence à elite e ao clero, não tendo sido relativamente acessível a outros estratos da população antes do final da Idade Média.

O que tem ocorrido é o uso de medidas (históricas, políticas, culturais) desenvolvidas em uma tradição (a nossa, europeia, ocidental) para enxergar, compreender e consertar outras tradições. Bessa Freire (2008) lembra o caso do cronista espanhol Gaspar de Carvajal, que contou ter visto elefantes em sua viagem pela Amazônia no século XVI ("animais que são grandes e têm trombas") - ele não conhecia a anta. Da mesma forma, é impreciso pensar que algumas sociedades ameríndias não desenvolveram um sistema de dominação estatal, ou abdicaram dessa possibilidade, no lugar de pensar que esse sistema não fazia

Espaço Ameríndio, Porto Alegre, v. 7, n. 1, p. 287-308, jan./jun. 2013. 
ALANA FRIES - Daniel Munduruku e Kaka Werá Jecupé...

sentido para suas estruturas organizacionais e a necessidade de instaurá-lo nunca existiu. Não estamos tratando de sociedades que eram carentes de escrita, mas sim independentes dela (BESSA FREIRE, 2008).

Assim, é preciso reformular a ideia de que a oralidade é uma etapa cultural a ser superada e assumir a legitimidade desse outro mecanismo de registro, transmissão e atualização de saberes históricos e culturais, que às vezes é diferente daqueles da "gente das cidades, que precisa guardar nos livros seu medo do esquecimento" (MUNDURUKU, 2008, n./p.).

No lugar de teorias famosas sobre a oralidade, parece mais interessante tentar alcançar seu significado para e a partir dos indivíduos que vivem essa tradição oral. Assim, dois trechos dos escritores indígenas que serão discutidos detalhadamente mais adiante neste trabalho:

Detentores que são de um conhecimento ancestral aprendido pelos sons das palavras dos avôs e avós antigos estes povos [indígenas] sempre priorizaram a fala, a palavra, a oralidade como instrumento de transmissão da tradição obrigando as novas gerações a exercitarem a memória, guardiã das histórias vividas e criadas (MUNDURUKU, 2008, n./p.).

A memória cultural se baseia no ensinamento oral da tradição, que é a forma original da educação nativa, que consiste em deixar o espírito fluir e se manifestar através da fala aquilo que foi passado pelo pai, pelo avô e pelo tataravô. (...) Um narrador da história do povo indígena começa um ensinamento a partir da memória cultural do seu povo, e as raízes dessa memória começam antes de o Tempo existir (JECUPÉ, 1998, p. 26).

Portanto, uma tradição oral não só compreende um conjunto de ensinamentos herdados, narrativas e práticas ou um mero instrumento, ela é parte constituinte desse ser que a possui e também a integra.

Concomitantemente às práticas orais, as sociedades ameríndias sempre tiveram suas próprias escritas (os Astecas e os Maias, por exemplo, tinham sistemas complexos de ideogramas ou pictogramas, não são consideradas pelos historiadores sociedades ágrafas), ainda que 
ALANA FRIES - Daniel Munduruku e Kaka Werá Jecupé...

não fonéticas e alfabéticas:

A memória cultural também se dá através da grafiadesenho, a maneira de guardar a síntese do ensinamento, que consiste em escrever através dos símbolos, traços, formas e deixar registrado no barro, no trançado de uma folha de palmeira transformado em cestaria, na parede e até no corpo, através de pinturas feitas com jenipapo e urucum (JECUPÉ, 1998, p. 26).

Um corpo pintado não é somente um corpo pintado: as formas traçadas podem simbolizar o pertencimento a um determinado clã ou a posição social dentro da aldeia; as pinturas de guerra carregam a força da tradição guerreira, as bênçãos dos deuses e antepassados. Os padrões de trançado numa cesta não são aleatórios, são próprios do artesão, que lhe confere significados e estabelece marca autoral. Então essas formas de escrita, como nos fala Kaka Jecupé, também têm função na manutenção da memória cultural, também criam e recriam constantemente tradições, identidades, autores e leitores.

Há também notícia de outros tipos de representações formais entre alguns povos indígenas brasileiros, como os Sateré-Maué do Amazonas, que

(...) preservam com muito cuidado três exemplares do Porantim - uma clava em forma de remo, trabalhadas em pau-ferro, onde estão gravados losangos e gregas, desenhos e figuras que representam simbolicamente um conjunto de mitos e histórias, com informações sobre as origens da tribo. Os desenhos do Porantim têm valor mnemônico. Até hoje alguns velhos são capazes de ler o seu conteúdo (BESSA FREIRE, 2008, p. 16-17).

Ruth Finnegan (2006) aponta como a literatura parece, para as culturas "letradas", constituir a própria essência da expressão intelectual, e que assumir que povos "não letrados" não têm literatura seria o mesmo que assumir que esses povos não se expressam intelectual e logicamente sobre aquilo que vivem, pensam e acreditam. Mas por que não teriam literatura?

No meu pensamento, a literatura indígena não é a literatura do livro, o livro é um instrumento da 
ALANA FRIES - Daniel Munduruku e Kaka Werá Jecupé...

literatura. Mas eu entendo que dançar a dança indígena é literatura, é uma conversa com os espíritos ancestrais. O canto indígena é literatura, é poesia pura do jeito tradicional de ser. Os rituais que se faz, os ritos de passagem, as narrativas que são passadas, são recontadas, são atualizadas pelos velhos da aldeia, é pura literatura, porque ela tem essa função de jogar quem escuta, jogar quem participa no coração do mundo (MUNDURUKU, 2011, n./p.) ${ }^{4}$.

A definição de literatura indígena dada pelo escritor Daniel Munduruku poderia ter saído diretamente dos textos acadêmicos que postulam os modernos conceitos de literatura oral (ou vice-versa). Agregando a definição de Idelette Muzart, que diz que o texto literário oral está "sempre inserido num discurso, como mensagem em situação" (SANTOS, 1995, p. 39), e o conceito de etnotexto ${ }^{5}$ da mesma autora, estamos prontos pra aceitar outras formas de literatura que vão além da escrita e da construção puramente formal do livro.

A partir da chegada do europeu, entretanto, os povos nativos passaram gradualmente a ser introduzidos em outra tradição de escrita. Tendo em vista que o objetivo deste trabalho não é analisar minuciosamente o processo histórico de alfabetização indígena, saltaremos no tempo até 1988, ano da publicação da Constituição Federal que garantiu aos índios o direito a uma educação diferenciada, que prezasse, inclusive, pela valorização de suas línguas maternas. Ainda que longe de ideais, as políticas indigenistas para educação avançaram significativamente: existem hoje escolas dentro das comunidades que atendem a parâmetros curriculares específicos para os povos indígenas, assim como escolas fora das aldeias mais ou menos preparadas para receber o aluno indígena.

O pai me disse que era uma maneira de nos defendermos [frequentar a escola]. Perguntei o que era escola. Me respondeu que era um lugar onde se riscava com traços o que se falava, e que qualquer um podia dizer exatamente o que se havia falado olhando para aqueles traços, mesmo que se passassem sóis e luas (JECUPÉ, 2002, p. 31).

\footnotetext{
${ }^{4}$ Transcrição minha da entrevista concedida à revista Nova Escola.

5 "Discurso que um grupo social, uma coletividade, elabora sobre sua própria cultura, na diversidade de seus componentes, e através do qual reforça ou questiona a sua identidade" (SANTOS, 1995, p. 39).
}

Espaço Ameríndio, Porto Alegre, v. 7, n. 1, p. 287-308, jan./jun. 2013. 
ALANA FRIES - Daniel Munduruku e Kaka Werá Jecupé...

Existe certa resistência por parte da sociedade envolvente em aceitar que um índio pode aprender a ler e escrever, em português e/ou língua materna; assim como o imaginário institucionalizado acerca dos povos indígenas é violado quando nos deparamos com um índio vestido, falando ao celular ou frequentando a universidade. Forçamos os povos indígenas a se adequarem aos nossos paradigmas sociais e culturais, mas somente com a condição de que deixe de ser índio, ou pelo menos que deixe de ser o índio que queremos que seja.

É preciso aceitar que o domínio da tecnologia de escrita por parte do indígena não traduz perda de identidade ou falta de vínculo com a tradição. "A escrita é uma técnica. É preciso dominar esta técnica com perfeição para poder utilizá-la a favor da gente indígena. Técnica não é negação do que se é. Ao contrário, é afirmação de competência" (MUNDURUKU, 2008, n./p.).

\section{Literaturas escritas indígenas}

Lynn Mário de Souza (2006) traça um panorama da escrita indígena no Brasil contemporâneo, dividindo-a em três grupos: 1) a escrita por intermédio de autores não indígenas (os registros recriações, transcriações - das narrativas orais dos povos indígenas); 2) a escrita tutelada por instituições não indígenas (caso dos livros didáticos feitos por professores indígenas para as escolas indígenas); e 3) a escrita dos autores de origem indígena integrados na cultura dominante ${ }^{6}$.

No primeiro caso, é importante perceber que registrar as narrativas orais não dá conta de toda sua complexidade. Ora, ao se contar uma história ou entoar um canto ritual, outros elementos estão envolvidos, como a expressão corporal, a entonação da voz, pausas dramáticas, a interferência de uma plateia específica etc. Esses artifícios específicos da oralidade, somados ao ato social e dinâmico que é a performance, se perdem no processo de transcrição.

\footnotetext{
${ }^{6}$ Note-se que o índio está presente na literatura brasileira desde sempre, através dos relatos de viajantes, no indianismo romântico, nas produções indigenistas etnográficas, na literatura científica e em outras publicações, como as de Mário de Andrade, Lima Barreto, Antonio Callado e Darcy Ribeiro. Não trataremos dessas literaturas aqui, pois o foco é na produção de autoria indígena.
}

Espaço Ameríndio, Porto Alegre, v. 7, n. 1, p. 287-308, jan./jun. 2013. 
ALANA FRIES - Daniel Munduruku e Kaka Werá Jecupé...

A esse tipo de registro se acresce um conflito que diz respeito à autoria: quem é o autor de uma coletânea de narrativas orais? Aquele que as coletou e organizou? Aqueles que as (re)produziam quando foram coletadas? Essas narrativas orais, cantos, preces não têm um só autor; são transmitidas de geração a geração e, como muitas outras coisas nas sociedades indígenas, são de 'propriedade' coletiva. A autoria se dá no momento da performance, quando aquele que detém esses conhecimentos o está transmitindo a outras pessoas, que serão também autores ao transmiti-los novamente em outro momento, e assim por diante.

Outro aspecto é o da atualização dessas poéticas orais. No momento em que é transposta à escrita, eterniza-se, de uma certa forma. Não há meios possíveis de dizer que aquela versão registrada é a mais fiel ou é a original e que daquela maneira permanecerá sendo (re)contada. Muito pelo contrário, essas poéticas só sobrevivem se constantemente atualizadas, e só são constantemente atualizadas porque o grupo que as mantém vê necessidade em mantê-las. Assim, embora esse trabalho de registro/transcrição seja excelente no sentido de que pelo menos uma parte dessas poéticas poderão ser acessadas por outros grupos em outros tempos-espaços, é imprescindível aceitar que não são absolutas ou definitivas, e que não dão conta da complexidade da tradição e transmissão oral.

Sobre o segundo tipo de literatura indígena, Lynn Mário de Souza:
A constituição de 1988, que oficialmente reconheceu a existência das línguas indígenas no Brasil, abriu o caminho para a educação bilíngüe indígena e levou à criação da nova instituição da escola indígena, reforçando assim o esforço dessas comunidades para a recuperação de suas culturas, muito embora cada comunidade sempre tivesse seus próprios meios para a transmissão de suas tradições orais (SOUZA, 2006, n./p.).

A partir da implantação dessa política de educação indígena, surge a necessidade de materiais didáticos para essas escolas, assim como um novo público leitor, que necessitaria também de textos paradidáticos nas suas línguas nativas. Assim, professores passam a ser preparados e especializados em educação indígena, assim como começa

Espaço Ameríndio, Porto Alegre, v. 7, n. 1, p. 287-308, jan./jun. 2013. 
ALANA FRIES - Daniel Munduruku e Kaka Werá Jecupé...

a formação de professores indígenas para atuarem nessas escolas. Uma vez envolvidos no processo educacional, aparece o movimento de contar a história e a cultura indígena pelo olhar do próprio indígena, e os meios para tanto começam a ser democratizados.

Nesse processo, as comunidades indígenas passam a ter acesso a outras plataformas de expressão e novas tecnologias. Hoje existem projetos como o Vídeo nas Aldeias7, criado pelo cineasta Vincent Carelli, que leva a produção audiovisual para dentro das comunidades, que realizam seus próprios filmes com o auxílio técnico da equipe do projeto. Outro belíssimo projeto, dentre muitos que poderiam ser citados aqui, é o realizado pela Apina - Conselho das Aldeias Wajãpi8. Os Wajãpi são famosos por seus grafismos, chamados kusiwa, reconhecidos pela Unesco como Obra-prima do Patrimônio Oral e Imaterial da Humanidade. Com o auxílio de outras entidades, a Apina realiza um projeto de formação de pesquisadores wajãpi, que organizam publicações onde registram seus patrimônios culturais como histórias, técnicas de agricultura e conhecimentos medicinais - na própria língua wajãpi ${ }^{9}$.

Dessa forma, encontramos agora os protagonistas deste trabalho, os autores indígenas que têm surgido no cenário literário e editorial brasileiro. Souza (2006) caracteriza esse grupo como

Escritores declaradamente de origem indígena (Daniel Munduruku, Kaká Werá Jecupé e Olívio Jekupé), mas que migraram para os centros urbanos nacionais, $\mathrm{e}$ conviveram com a cultura dominante, escrevendo de e para a cultura dominante não indígena (SOUZA, 2006, n./p.).

A afirmação de que escrevem da cultura dominante é um pouco delicada, contudo. Parece mais acertado dizer que eles escrevem a partir de sua cultura indígena através dos meios da cultura dominante.

Entre os atuais escritores indígenas no Brasil mais lembrados estão, por exemplo, Daniel Munduruku, Kaka Werá Jecupé, Yaguraê Yamã, Eliane Potiguara e Olívio Jekupé. De fato, todos têm experiência

\footnotetext{
${ }^{7}$ http://www.videonasaldeias.org.br .

8 http://www.apina.org.br .

9 Algumas dessas publicações estão disponíveis em formato PDF neste endereço: http://www.apina.org.br/patrimonio_imaterial.html .
}

Espaço Ameríndio, Porto Alegre, v. 7, n. 1, p. 287-308, jan./jun. 2013. 
ALANA FRIES - Daniel Munduruku e Kaka Werá Jecupé...

na cidade, e, com exceção de Kaka, formação acadêmica em algum nível; mas suas produções focam na cultura indígena, seja através de histórias infantis, autobiográficas, poéticas, didáticas, etc. É interessante notar que esses autores carregam um histórico de ativismo político, de luta pela valorização e sobrevivência da cultura indígena.

Superadas as fronteiras da língua, da cultura, da marginalização histórica e do preconceito, esses autores ainda precisam lidar com o mercado editorial, tradicionalmente restrito e focado, principalmente, em publicações que garantirão retorno financeiro. Daniel Munduruku, porém, já chegou a publicar pela Companhia das Letras, um grande grupo editorial brasileiro bastante conceituado.

A seguir, uma análise individual de duas obras de autoria indígena, através das quais buscaremos compreender alguns aspectos dessa literatura e de que maneira ela pode ser apreendida pela sociedade não indígena. O que é que estão tentando nos dizer? "Eu vim pra mostrar a nudez do meu povo. A claridade do coração. Eu vim para nos despirmos. Para descobrirmos os brasis. Para descobrirmos os brasileiros. Para conversarmos junto ao pé do fogo" (JECUPÉ, 2002, p. 17).

\section{A maior contribuição do indígena para a cultura brasileira? Manter-se vivo ${ }^{10}$}

Karaíba: uma história do pré-Brasil narra o envolvimento de três comunidades que lutam para sobreviver ao tempo difícil pelo qual estão passando, para compreender a profecia anunciada pelo velho Karaíba de que tempos mais difíceis ainda estão por vir. A história envolve os povos Tupiniquim e Tupinambá, habitantes da costa brasileira e primeiros a ter contato com o europeu. O que amarra a história é a profecia sobre o nascimento do "filho que irá unir nossos povos contra os irmãosfantasmas" (MUNDURUKU, 2010, p. 1). Assim, o destino de três comunidades (uma delas inimiga) depende de superarem suas diferenças para unirem-se contra o inimigo comum. Esse não deixa de ser o caminho que os povos indígenas tiveram que seguir para

\footnotetext{
${ }^{10}$ Título adaptado da declaração de Daniel Munduruku em entrevista concedida a João Rocha (2011) para o Almanaque Brasil.
}

Espaço Ameríndio, Porto Alegre, v. 7, n. 1, p. 287-308, jan./jun. 2013. 
ALANA FRIES - Daniel Munduruku e Kaka Werá Jecupé...

sobreviver à dominação branca. Remanescentes de comunidades devastadas tiveram que abrigar-se em outras comunidades, até mesmo o casamento interétnico passou a ser relativamente aceito. O próprio Kaka Werá Jecupé nasceu tapuia, mas tornou-se guarani. É claro que as lideranças indígenas lutam por terras para sua comunidade e pela sobrevivência de seu povo, mas é nítido no discurso indígena o entendimento de que isso só é possível a partir da união de todos os parentes indígenas. Respeitadas as diferenças entre os povos nativos, eles têm uma coisa muito forte em comum, a luta por sobrevivência e dignidade.

O velho Karaíba é um ser quase mágico ou mítico:

Sua chegada sempre era um espetáculo, pois se postava na entrada da aldeia e algumas pessoas iam varrendo o local por onde ele passava. Era tratado como grande sábio e profeta, merecendo o respeito de todos (MUNDURUKU, 2010, p. 77).

Como uma espécie de pajé, ele tem acesso às palavras enviadas pelos seres que habitam outros mundos, é um narrador que transmite os saberes alheios, distantes no espaço. Perna Solta explica:

- Nossa tradição, pequena Maraí, sempre foi movida pela fé nos sinais que esses sábios nos trouxeram. Por muito tempo eles nos deram demonstrações de que sabem dominar a leitura do tempo. Não cabe a nós ficar questionando essa sabedoria milenar. Afinal, para nós, eles são Maíra, espécie de amigos íntimos do Criador e que nos falam as palavras sagradas vindas Dele (MUNDURUKU, 2010, p. 3).

Já apresentados à Potyra, a menina que queria ser guerreira (e, saberemos depois, é a mulher que vai gerar o filho citado na profecia), uma velha da aldeia lembra o tempo das Icamiabas ${ }^{11}$. Talvez o importante neste trecho não seja a história em si, mas alguns elementos da cena:

\footnotetext{
${ }^{11} \mathrm{O}$ mito das Icamiabas, as mulheres guerreiras que matavam e escravizavam os homens na Amazônia, é alvo de debate entre estudiosos desde os primeiros tempos de Brasil. Diversos cronistas alegaram ter visto a tribo das mulheres sem maridos. Há quem diga que obteve dos próprios indígenas informações sobre essas mulheres. Fato é que é um mito antigo, possivelmente adaptado das culturas Clássicas, e que há muito tempo faz parte do folclore brasileiro.
}

Espaço Ameríndio, Porto Alegre, v. 7, n. 1, p. 287-308, jan./jun. 2013. 
ALANA FRIES - Daniel Munduruku e Kaka Werá Jecupé...

- A história é contada por uma velha, a quem as crianças chamam de vovó. O idoso é figura importante e muito respeitada dentro das sociedades indígenas, pois ele carrega a sabedoria de quem viveu outros tempos, carrega a sabedoria ancestral e a experiência de vida, é através dos idosos da comunidade que as crianças aprenderão sobre sua própria história - Daniel Munduruku trata disso em seu livro Meu vô Apolinário (2001), da figura do idoso na formação cultural e identitária do indígena, a partir da própria experiência.

- A nítida situação de performance produzida pela figura do narrador (descrita no item anterior) e por uma audiência interessada e parte integrante do desenvolvimento da narrativa: "E como elas tinham filho? - quis saber uma voz curiosa no meio do público" (MUNDURUKU, 2010, p. 48), a intervenção do ouvinte ajuda a definir os caminhos que tomará a narrativa, ou seja, compartilhando autoria; "- Até hoje, os homens não servem pra nada - disse alguém arrancando muitas risadas dos presentes" (MUNDURUKU, 2010, p. 50), a recontextualização da narrativa, ou seja, a permissão concedida pelo público, que a valida.

- No fim, a própria narradora explica os mecanismos que a levam a estar ali contando aquela história, a motivação para a permanente atualização do mito/história que vem de tempos imemoriais e o que permite a existência de uma audiência: "Lendas são histórias criadas para contar verdades que nossas cabeças não conseguem alcançar" (MUNDURUKU, 2010, p. 50).

No capítulo 13, "Lua nova", o leitor acompanha a preparação tupiniquim para a guerra. Não só a guerra em si é importante para algumas sociedades indígenas de tradição guerreira, também os elementos ritualísticos que a acompanham nos ajudam a compreender melhor as visões de mundo, crenças e recursos simbólicos desses povos.

Os guerreiros se levantam e preparam suas armas, enquanto as mulheres acendem o fogo para preparar o alimento. O lamento ritual das mães enquanto pintam os corpos de seus filhos:

Meu filho é sangue do meu sangue/ Vai honrar seu pai e sua mãe./ Vai mostrar ao inimigo que somos feitos/

Espaço Ameríndio, Porto Alegre, v. 7, n. 1, p. 287-308, jan./jun. 2013. 
ALANA FRIES - Daniel Munduruku e Kaka Werá Jecupé...

De passado e de presente./ Vai levar as marcas da nossa gente/ $\mathrm{E}$ matar o inimigo com honra e prestígio (MUNDURUKU, 2010, p. 55).

O pajé lidera a cerimônia, “(...) conclama as forças dos antepassados fazendo-os [os guerreiros] repetirem inúmeras vezes palavras de vitória e alegria" (MUNDURUKU, 2010, p. 56).

De posse do cachimbo alcançado pelo pajé, o chefe Anhangá fala ao Pai Nhanderuvuçu:

És nosso pai primeiro, criador das belezas deste mundo que nos ofereceste para dominar. Somos gratos por isso. Somos gratos também pelos nossos pais antepassados que se sacrificaram para que pudéssemos estar aqui. Estamos indo para a guerra, Pai. Vamos buscar os filhos que nos foram roubados e traremos crianças para serem educadas na verdade de nossa tradição. E traremos mulheres para que possam ser mães de verdade, para que possam encontrar guerreiros verdadeiros para serem pais de seus filhos. (MUNDURUKU, 2010, p. 56)

É interessante perceber que inicialmente o discurso não é de tolerância entre os povos indígenas; eles lutam entre si e fazem prisioneiros, porque a sua tradição é a verdadeira. É um tipo de etnocentrismo que, na verdade, garantiu a diversidade cultural durante muito tempo. É um instinto natural de sobrevivência, tanto quanto o é caçar para comer.

A guerra congrega uma tradição social e reflexo instintual de sobrevivência, a simbologia da pintura corporal, o ato-ritual de invocação dos antepassados, a atenção aos valores e crenças religiosas/espirituais; representa um momento liminar para os jovens guerreiros, que vão cumprir o papel para o qual foram preparados desde a infância, e para o líder da comunidade, que tomará as decisões e é responsável pelo destino de todos.

Esses três elementos da narrativa em questão - o profeta, a velhanarradora e a guerra - foram selecionados por um motivo. Sem nunca renegar sua origem munduruku, o autor apresenta aspectos comuns a várias sociedades tradicionais. Parece que consegue escapar ao conceito convencional de obra literária enquanto produto individual ao dar voz a talvez milhões de índios que já habitaram estas terras. Esse 
ALANA FRIES - Daniel Munduruku e Kaka Werá Jecupé...

entendimento não supõe que não haja marca de autoria, que o autor se abstenha de exercer sua subjetividade. Pelo contrário, ele só é possível através da habilidade técnica e estética do autor.

A chave para a reflexão permanece nas palavras proféticas do velho Karaíba:

Fantasmas dos antepassados chegarão nesta terra e tornarão nossos povos escravos de sua ganância. Eles não terão piedade nem dos velhos nem das crianças. Simplesmente se sentirão donos desse lugar e de sua gente (MUNDURUKU, 2010, p. 78).

Não sobrarão vestígios de nossa passagem sobre esta terra onde nossos pais viveram. Os monstros virão e destruirão nossa memória e nossos caminhos. Tudo será revirado: as águas, a terra, os animais, as plantas, os lugares sagrados. Tudo (MUNDURUKU, 2010, p. 2).

Daniel Munduruku nasceu em Belém e foi criado numa aldeia no interior do estado do Pará. Aos 15 anos foi estudar numa escola na cidade, quando a política estatal ainda era a de incorporação total do índio à sociedade "civilizada": era castigado se falasse em sua língua materna e não em português. Resistiu. Mudou-se para São Paulo, onde se tornou um dos primeiros indígenas doutores do país. Não esconde o desapontamento quando é chamado de índio: "índio não, munduruku". Da experiência de educador e de índio na cidade, compreendeu que a distância entre a cultura indígena e a cultura ocidental vinha do susto, do estranhamento; e que isso não mudou desde a chegada dos primeiros europeus. Decidiu que a palavra seria sua flecha, e que usaria a literatura para aproximar, especialmente a crianças, do universo indígena, e, quem sabe assim, todos se conhecendo um pouco mais, o medo e o conflito deem lugar ao respeito.

Esse escritor que conhecemos por Daniel Munduruku12 tem, na verdade, outro nome, um nome indígena e sagrado que honra um antepassado seu e só pode ser revelado pessoalmente. Tem mais de 40 livros publicados, diversos prêmios nacionais e internacionais na área de literatura infantil e juvenil e a responsabilidade de dirigir o Instituto UKA

\footnotetext{
${ }^{12}$ As fontes das informações biográficas de Daniel Munduruku provêm de meios eletrônicos e estão devidamente citadas nas referências deste trabalho, são elas: Almanaque Brasil, Revista Recreio e Mundurukando.
}

Espaço Ameríndio, Porto Alegre, v. 7, n. 1, p. 287-308, jan./jun. 2013. 
ALANA FRIES - Daniel Munduruku e Kaka Werá Jecupé...

- Casa dos Saberes Ancestrais e o Instituto Indígena Brasileiro para a Propriedade Intelectual (INBRAPI). Mas que índio é esse com Currículo Lattes?

\section{Aqui onde se expulsa com documentos do imperador ${ }^{13}$}

Todas as vezes que dissemos adeus conta a jornada de um homem-narrativa, Kaka Werá Jecupé, índio de origem tapuia, mas criado entre os Guarani de São Paulo, em busca dos meios e compreensões necessários para cumprir a missão que lhe foi dada:

Sonhei que os Tamãi deram-me a incumbência de contar um pouco da minha história, da minha vida entre dois mundos, e de relevar alguns mistérios da tradição milenar ensinada pelos Antigos, os que aqui habitavam desde sempre. Neste sonho firmei 0 compromisso de traduzir da vermelha 'escrita-pintura' de meu corpo para o branco corpo desta 'pinturaescrita' (JECUPÉ, 2002, p. 16).

O evidente conflito por que passa o autor nasce da necessária participação na sociedade dominante, a qual questiona e não compreende. Talvez a expressão "olhar do outro" não pudesse ser melhor explicada do que quando Kaka chama o rabino de pajé judeu, ou a igreja de opy. Quando "Tiramãe Tujá olhou a famosa imagem do Rio. O Cristo Redentor. Eu também observava pela primeira vez. Perguntoume: - É Nandejara-Tupã?" (JECUPÉ, 2002, p. 58); quando fala da tomada da aldeia de seus pais e dos "homens empunhados de pequenos trovões de aço" (JECUPÉ, 2002, p. 22). Ou então quando descreve uma parte da participação na produção de uma minissérie que adaptaria $O$ Guarani, de José de Alencar:

Os ladrões [de almas] procuravam fazer com que o espírito preso da manhã de sol nascendo na caixa mágica se aproximasse ao máximo da manhã de sol roubada. O lugar dessas feitiçarias chama-se 'ilha de edição' (JECUPÉ, 2002, p. 56).

\footnotetext{
${ }^{13}$ Adaptado de Jecupé (2002, p. 16).
} 
ALANA FRIES - Daniel Munduruku e Kaka Werá Jecupé...

Kaka vê o mundo assim, através dos olhares que aprendeu a ter na aldeia. Se as ruas e avenidas das cidades são trilhas grandes ou pequenas, se esses papéis que o homem branco usa pra legitimar as coisas são todos documentos, se algumas tecnologias são feitiçaria; não consigo deixar de pensar que se visitasse uma aldeia, chamaria todas as árvores de árvore, todos os animais de bicho e todos os ventos de ventania, e sabe-se lá quantas coisas não enxergaria por não ter aprendido esses outros olhares.

O choque cultural é muito evidente. Os indígenas estão obrigados a interagir num mundo - e estão sujeitos aos mecanismos dele - que não necessariamente compreendem plenamente. É uma arte aprender outros olhares; acontece que a sociedade não indígena não precisa necessariamente aprendê-los. Já eles, precisam de números pra existir de verdade, papel que diga que podem plantar, lei que diga que podem ser índio.

Um dia chegou um senhor com uns papéis na mão dizendo que o lugar onde morávamos era dele, doado por d. Pedro II. - Filho, procure esse tal d. Pedro que eu quero falar com ele - disse o pai. Estou procurando até hoje (JECUPÉ, 2002, p. 34).

Kaka é pahi, uma espécie de pajé, lida com espíritos ancestrais e da natureza. Ao longo de seu trajeto, encontra outros líderes espirituais de diversas vertentes que o ajudam a entender a si mesmo. É uma trajetória de autoconhecimento e de retorno às origens indígenas, não deixa de lembrar a busca pela Terra Sem Males, a Ivy-Marãen. Assim, sua narrativa não é linear e tampouco objetiva. Percorre constantemente suas próprias memórias, recebe visitas e encontra seres com quem compartilha experiências espirituais e ritualísticas.

O título do livro também não parece à toa: descobrimos todos os adeus que Kaka precisou dar ao longo de sua trajetória, e eles simbolizam os constantes deslocamentos e estranhamentos desse indígena que se sente estrangeiro em sua própria terra. Do adeus que seus antepassados precisaram dar as suas terras originárias, o adeus aos pais que não resistiram à nova vida próxima da cidade e de seus paradigmas, adeus ao amigo de infância que não resistiu ao banho que tomaram nas águas da represa que cercava a aldeia, o adeus a sua

Espaço Ameríndio, Porto Alegre, v. 7, n. 1, p. 287-308, jan./jun. 2013. 
ALANA FRIES - Daniel Munduruku e Kaka Werá Jecupé...

própria ancestralidade tapuia que deu lugar ao ser guarani que se tornou:

\begin{abstract}
É longe e ao mesmo tempo agora e aqui que me vem a última vez em que vi Tirajy, Meirê-Mekrangnorite, maino, a Vó colibri me contando as últimas sílabas da memória de nossa aldeia; me contando o modo da gente, a maneira, o meio. Meio este que não sou mais. Sendo agora um modo, uma maneira e um meio guarani de contar o já contado pelo destino (JECUPÉ, 2002, p. 63).
\end{abstract}

Nesse e em outros livros, como $A$ terra dos mil povos (2008), existe também um claro propósito de mostrar detalhes da cultura indígena. Seus mitos de origem, seus rituais, suas formas de se relacionar, a diferença entre cada um dos povos nativos, a relação com a natureza. Pois aceitou "por inteiro a missão de ser porta-voz à surda metrópole com seus ornamentos de néon e a beleza cosmética de sua face", cujos habitantes e antepassados vestiram o povo indígena de “costumes, hábitos e espelhos" (JECUPÉ, 2002, p. 16).

\title{
Conclusão
}

Considerando que hoje são aproximadamente 800.000 indígenas, 250 povos e 150 línguas ainda vivas, mas que já foram milhões de indígenas e mais de 1000 povos e línguas, a dimensão do patrimônio cultural que ignoramos e aquela parcela que ignoraremos para sempre, pois já há muito se perdeu, é inconcebível.

Daniel Munduruku e Kaka Werá Jecupé realizam um trabalho que nos aproxima do universo indígena praticamente sem intermediários, regalando a toda sociedade a oportunidade de vislumbrar noções e entendimentos de mundo vivos, desde a voz daqueles que as sustentam. Porém, buscar compreender como esses escritores se propõem a disseminar a sabedoria de seus povos e de que maneira eles lidam e entendem as tensões entre as culturas indígena e não indígena é essencial durante a leitura dessas obras.

O desenvolvimento de uma literatura indígena e sua colocação no cenário sociocultural é não só um processo de apropriação de meios

Espaço Ameríndio, Porto Alegre, v. 7, n. 1, p. 287-308, jan./jun. 2013. 
ALANA FRIES - Daniel Munduruku e Kaka Werá Jecupé...

tradicionalmente restritos, mas também um importante passo dado em direção ao estabelecimento de um canal de comunicação entre o cidadão indígena e o cidadão não indígena, sem a mediação de instituições políticas ou acadêmicas, o que vem a desmistificar os povos nativos, diminuir o medo daquilo que parece distante e diferente demais, e enriquecer as possíveis relações e trocas interculturais.

\section{Referências bibliográficas}

BALDUINO, Ludmilla. Escritor Daniel Munduruku fala sobre a vida dos povos indígenas. In: RECREIO. [Seção Fique Ligado]. 20 nov. 2012. Disponível em: http://www.recreio.com.br/fique-ligado/escritor-daniel-munduruku-fala-sobre-a-vidados-povos-indigenas. Acesso em: 5 dez. 2012.

BESSA FREIRE, José Ribamar. A canoa do tempo: tradição oral e memória indígena. In: TAQUI PRA TI. [Acervo de produção acadêmica]. 2008. Disponível em: http://www.taquiprati.com.br/arquivos/pdf/Acanoa_do_tempo_versaoUFAC2008.pdf. Acesso em: 17 nov. 2012.

CAMINHA, Pero Vaz de. A Carta. Disponível em: http://www.dominiopublico.gov.br/pesquisa/DetalheObraForm.do?select_action=\&co obra=17424 . Acesso em: 17 nov. 2012.

FINNEGAN, Ruth. O significado da literatura em culturas orais. In: QUEIROZ, Sônia (Org.). A tradição oral. Belo Horizonte: FALE/UFMG, 2006. p. 64-104. Disponível em: http://www.letras.ufmg.br/vivavoz/data1/arquivos/tradicaooral-site.pdf. Acesso em: 2 dez. 2012.

HAVELOCK, Eric. A equação oralidade - cultura escrita: uma fórmula para a mente moderna. In: OLSON, David R.; TORRANCE, Nancy (Org.). Cultura escrita e oralidade. São Paulo: Ática, 1995. p. 17-34.

JECUPÉ, Kaka Werá. A terra dos mil povos: história indígena brasileira contada por um índio. São Paulo: Peirópolis, 1998.

Todas as vezes que dissemos adeus. São Paulo: TRIOM, 2002.

LIGÓRIO, Ludmila Martins. Problematizando representações acerca dos povos indígenas: uma experiência fundamental. In: BERGAMASCHI, Maria Aparecida (Org.). Povos indígenas \& educação. Porto Alegre: Mediação, 2008. p. 109-124.

MUNDURUKANDO. Disponível em: http://danielmunduruku.blogspot.com.br. Acesso

Espaço Ameríndio, Porto Alegre, v. 7, n. 1, p. 287-308, jan./jun. 2013. 
ALANA FRIES - Daniel Munduruku e Kaka Werá Jecupé...

em: 7 dez. 2012.

MUNDURUKU, Daniel. Meu vô apolinário: um mergulho no rio da (minha) memória. São Paulo: Studio Nobel, 2001.

Literatura indígena e o tênue fio entre escrita e oralidade. In: OVERMUNDO.

[post]. 30 nov. 2008. Disponível em:

http://www.overmundo.com.br/overblog/literatura-indigena. Acesso em: 22 nov. 2012.

O Karaíba: uma história do pré-Brasil. São Paulo: Manole, 2010.
. Entrevista. In: NOVA ESCOLA. Entrevista com Daniel Munduruku - Parte
1. 14 abr. 2011. 2min. 12s. Disponível em: http://www.youtube.com/watch?v=4kLFgqMXe6s\&list=PL7938F0FF53417B4A\&inde $\mathrm{x}=4$. Acesso em: 20 nov. 2012.

POVOS Indígenas no Brasil. Disponível em: http://pib.socioambiental.org/pt. Acesso em: 22 nov. 2012.

ROCHA, João. Daniel Munduruku. In: ALMANAQUE Brasil. [Seção Bons Exemplos]. 2011. Entrevista. Disponível em: http://www.almanaquebrasil.com.br/cultura/10634daniel-munduruku.html. Acesso em: 7 dez. 2012.

SANTOS, Idelette Muzart Fonseca dos. Escritura da voz e memória do texto: abordagens atuais da literatura popular brasileira. In: BERND, Zilá; MIGOZZI, Jacques (Org.). Fronteiras do literário: literatura oral e popular Brasil/França. Porto Alegre: EDUFRGS, 1995. p. 31-43.

SOUZA, Kelly. Tupi or not tupi? A identidade do Brasil pré-colonial na obra de autores índios e de escritores indigenistas. In: REVISTA da Cultura. [post]. Abr. 2009. Disponível em: www.revistadacultura.com.br:8090/revista/RC21/index2.asp?page=capa. Acesso em: 26 nov. 2012.

SOUZA, Lynn Mário de. Uma outra história, a escrita indígena no Brasil. 2006. Disponível em: http://pib.socioambiental.org/pt/c/iniciativas-indigenas/autoriaindigena/uma-outra-historia,-a-escrita-indigena-no-brasil. Acesso em: 17 nov. 2012.

VIVEIROS DE CASTRO, Eduardo. No Brasil, todo mundo é índio, exceto quem não é. In: RICARDO, Beto; RICARDO, Fany (Org.). Povos indígenas no Brasil: 2001-2005. São Paulo: Instituto Socioambiental, 2006, p. 41-49.

Espaço Ameríndio, Porto Alegre, v. 7, n. 1, p. 287-308, jan./jun. 2013. 